\title{
Bacterial versus fungal laccase: potential for micropollutant degradation
}

\author{
Jonas Margot ${ }^{1,2^{*}}$, Chloé Bennati-Granier ${ }^{1,4}$, Julien Maillard ${ }^{1}$, Paqui Blánquez ${ }^{3}$, David A Barry ${ }^{2}$ and Christof Holliger $^{1}$
}

\begin{abstract}
Relatively high concentrations of micropollutants in municipal wastewater treatment plant (WWTP) effluents underscore the necessity to develop additional treatment steps prior to discharge of treated wastewater. Microorganisms that produce unspecific oxidative enzymes such as laccases are a potential means to improve biodegradation of these compounds. Four strains of the bacterial genus Streptomyces (S. cyaneus, S. ipomoea, S. griseus and S. psammoticus) and the white-rot fungus Trametes versicolor were studied for their ability to produce active extracellular laccase in biologically treated wastewater with different carbon sources. Among the Streptomyces strains evaluated, only S. cyaneus produced extracellular laccase with sufficient activity to envisage its potential use in WWTPs. Laccase activity produced by T. versicolor was more than 20 times greater, the highest activity being observed with ash branches as the sole carbon source. The laccase preparation of S. cyaneus (abbreviated $L_{S_{C}}$ ) and commercial laccase from $T$. versicolor $\left(L_{T_{V}}\right)$ were further compared in terms of their activity at different $\mathrm{pH}$ and temperatures, their stability, their substrate range, and their micropollutant oxidation efficiency. $\mathrm{L}_{S c}$ and $\mathrm{L}_{T_{V}}$ showed highest activities under acidic conditions (around pH 3 to 5), but $\mathrm{L}_{T_{V}}$ was active over wider pH and temperature ranges than $\mathrm{L}_{s c}$ especially at near-neutral $\mathrm{pH}$ and between 10 and $25^{\circ} \mathrm{C}$ (typical conditions found in WWTPs). $L_{T}$ was also less affected by $\mathrm{pH}$ inactivation. Both laccase preparations oxidized the three micropollutants tested, bisphenol A, diclofenac and mefenamic acid, with faster degradation kinetics observed for $L_{T}$. Overall, T. versicolor appeared to be the better candidate to remove micropollutants from wastewater in a dedicated post-treatment step.
\end{abstract}

Keywords: Laccase; Streptomyces spp; Trametes versicolor; Micropollutant; Wastewater; Oxidation

\section{Introduction}

Many micropollutants present in municipal wastewater, such as pharmaceuticals or biocides, are not easily removed in conventional biological treatments, resulting in a constant input into the aquatic environment (Deblonde et al. 2011; Margot et al. 2013a). As these compounds are designed to be biologically active, they can affect sensitive aquatic organisms even at low concentrations (Alan et al. 2008; Bundschuh et al. 2011; Gagné et al. 2011). One potential means to reduce the amounts released to the environment is to improve their biodegradation in a

\footnotetext{
*Correspondence: jonas.margot@epfl.ch

1 Laboratory for Environmental Biotechnology, School of Architecture, Civil and Environmental Engineering (ENAC), Station 6, Ecole Polytechnique Fédérale de Lausanne (EPFL), 1015 Lausanne, Switzerland

${ }^{2}$ Ecological Engineering Laboratory, School of Architecture, Civil and Environmental Engineering (ENAC), Station 2, Ecole Polytechnique Fédérale de Lausanne (EPFL), 1015 Lausanne, Switzerland

Full list of author information is available at the end of the article
}

post-treatment step using microorganisms that produce oxidative enzymes such as laccases (Blánquez et al. 2008; Zhang \& Geißen 2012).

Laccases (EC 1.10.3.2) are polyphenol oxidases that catalyse the oxidation of various aromatic compounds, particularly those with electron-donating groups such as phenols $(-\mathrm{OH})$ and anilines $\left(-\mathrm{NH}_{2}\right)$, by using molecular oxygen as an electron acceptor (Gianfreda et al. 1999). Laccase enzymes are widespread among plants, fungi and bacteria, and have various biological functions, such as degradation of complex polymers (lignin, humic acid), lignification, detoxification, pathogenicity, morphogenesis, sporulation, polymerization of melanin and spore coat resistance (Strong \& Claus 2011). The ability of fungal laccases to catalyze (alone or with the help of mediators) the oxidation of pharmaceuticals and biocides was shown for several substances, such as endocrine compounds (Auriol et al. 2008; Cabana et al. 2007), analgesic and

\section{它}


anti-inflammatory drugs (Lu et al. 2009; Marco-Urrea et al. 2010; Margot et al. 2013b), antibiotics (Schwarz et al. 2010; Suda et al. 2012), UV filter (Garcia et al. 2011), biocides (Margot et al. 2013b) and various halogenated pesticides (Torres-Duarte et al. 2009). Due to their wide range of substrates and the sole requirement of oxygen as the co-substrate, laccases appear to be a promising biocatalyst to enhance the biodegradation of micropollutants in wastewater in a complementary treatment step.

In order to overcome the cost associated with the large amount of free laccase required in real applications (due to losses during the treatment), two strategies have been envisaged, i.e., (i) immobilization of the enzymes on solid supports in order to reuse them several times (Fernández-Fernández et al. 2012) or (ii) production of the enzyme during wastewater treatment using laccaseproducing microorganisms and cheap substrates (e.g., agriculture or forestry waste) (Libra et al. 2003). The latter option avoids expensive immobilization processes while it could further improve the degradation of micropollutants along with other oxidative enzymes produced by these organisms, such as peroxidases or oxygenases. It would, however, require growing and maintaining the laccase-producing organisms in the wastewater treatment plants (WWTPs), a process that is still little studied (Zhang \& Geißen 2012; Libra et al. 2003; Blánquez et al. 2006). While the extensively studied white-rot wooddegrading fungi such as Trametes versicolor are attractive candidates with their high production rates of extracellular lignolytic enzymes (Nyanhongo et al. 2007), very little is known about the potential of bacterial laccases for bioremediation applications. Wastewater treatment involving bacteria is, however, considered to be more stable, as bacteria generally tolerate a broader range of habitats and grow faster than fungi (Harms et al. 2011). Moreover, in contrast to fungal laccases, some bacterial laccases can be highly active and much more stable at high temperatures, at high $\mathrm{pH}$ as well as at high chloride concentrations (Bugg et al. 2011; Dwivedi et al. 2011; Reiss et al. 2011; Sharma et al. 2007).

Most bacterial laccases studied so far are located intracellularly, which is a disadvantage for micropollutant degradation (Sharma et al. 2007). However, some strains of Streptomyces spp. produce extracellular laccases, such as S. psammoticus MTCC 7334 (Niladevi et al. 2008a), S. cyaneus CECT 3335 (Arias et al. 2003), S. ipomoea CECT 3341 (Molina-Guijarro et al. 2009) or S. griseus NBRC 13350 (Endo et al. 2002). Moreover, laccases from $S$. psammoticus and S. ipomoea showed unusually high activity at the slightly alkaline $\mathrm{pH}$ values $(7-8)$ found in wastewater, as well as tolerance to high $\mathrm{NaCl}(>1 \mathrm{M})$ concentrations (Molina-Guijarro et al. 2009; Niladevi et al. 2008a). High laccase activity was also observed in the culture supernatant of S. psammoticus and S. cyaneus
(Arias et al. 2003; Niladevi et al. 2009), suggesting suitability of these strains for bioremediation applications.

The goal of this study was thus to assess the potential of four laccase-producing strains of Streptomyces bacteria, namely S. cyaneus CECT 3335, S. psammoticus MTCC 7334, S. ipomoea CECT 3341, and S. griseus NBRC 13350, together with the white-rot fungus $T$. versicolor, to select the best candidate for future use in municipal wastewater post-treatment, e.g., in a biotrickling or sand filter. More specifically, the goals were to study: (i) their ability to produce laccase in biologically treated wastewater on cheap substrates, such as agricultural, forestry or food industry wastes, in a sufficient quantity to oxidize the pollutants in a reasonable time $(<1 \mathrm{~d})$, (ii) their laccase activity at different $\mathrm{pH}$ and temperature in order to determine optimal conditions for wastewater treatment, (iii) the inhibition of laccase activity by compounds present in wastewater such as salts, (iv) laccase stability in the $\mathrm{pH}$ range potentially found in the treatment, and finally (v) the laccase substrate range and their ability to oxidize different phenolic and aniline micropollutants in the $\mathrm{pH}$ range found in wastewater.

\section{Materials and methods}

\section{Chemicals, choice of micropollutants, and commercial} laccase enzyme

Three micropollutants were selected as model compounds for this study because of their regular presence in municipal WWTP effluent at relatively high concentrations (average between 300-1000 $\mathrm{ng} \mathrm{l}^{-1}$ ) (Kase et al. 2011), their potential toxicity (Crain et al. 2007; Triebskorn et al. 2004) and because they are prone to oxidation by the laccase of $T$. versicolor (Margot et al. 2013b): the anti-inflammatory drugs mefenamic acid (MFA) and diclofenac (DCF), both aniline compounds, and the plastic additive bisphenol $\mathrm{A}$ (BPA), a phenolic substance.

BPA, DFC sodium salt, and MFA (purity > 97\%), laccase preparation from $T$. versicolor (ref. 38429, Sigma), 2,2'azino-bis(3-ethylbenzthiazoline-6-sulphonic acid) (ABTS), 2,6-dimethoxyphenol (DMP), syringaldazine and guaiacol were purchased from Sigma-Aldrich Chemie $\mathrm{GmbH}$ (Buchs, Switzerland). All other chemicals used were purchased from either Sigma-Aldrich or Fisher Scientific AG (Wohlen, Switzerland). Soy flour, spelt flour and oat bran, all from organic production, and spruce wood chips were purchased at a local supermarket (Coop, Lausanne, Switzerland). Wheat straw flour was purchased from Provimi Kilba (Cossonay, Switzerland). Dry rushes (Juncus genus, stem diameter: 0.2-0.4 mm), dry ash branches (Fraxinus genus, with bark, diameter of the branches: 0.3-0.7 $\mathrm{mm}$ ) and dry beech sawdust (Fagus genus) were collected in a wetland and in the forest next to L'Isle (Switzerland). Oat bran and spruce wood chips were ground to obtain fine particles $(<1 \mathrm{~mm})$. Ash branches 
and rushes were cut into sections of $0.5-1.0 \mathrm{~cm}$, washed with tap water and oven-dried for $24 \mathrm{~h}$ at $60^{\circ} \mathrm{C}$.

\section{Microorganisms and inoculum preparation}

Pure strains of S. cyaneus CECT 3335 and S. ipomoea CECT 3341 (from Spanish Type Culture Collection, Valencia, Spain), S. griseus NBRC 13350 (from NITE Biological Resource Center, Chiba, Japan) and S. psammoticus MTCC 7334 (from Microbial Type Culture Collection, Chandigarh, India) were cultivated in GYM streptomyces medium (DSMZ, medium 65 (in $\mathrm{g} \mathrm{l}^{-1}$ ): glucose -4 , yeast extract - 4, malt extract - 10, $\mathrm{pH} 7.2$ ) at $30^{\circ} \mathrm{C}$, $140 \mathrm{rpm}$ during $4 \mathrm{~d}$. Cell pellets were collected by centrifugation, washed 3 times with phosphate-buffered saline (PBS (in g l-1): $\mathrm{NaCl}-8, \mathrm{KCl}-0.2, \mathrm{Na}_{2} \mathrm{HPO}_{4}-1.44$, $\mathrm{KH}_{2} \mathrm{PO}_{4}-0.24, \mathrm{pH}$ 7.4) and then stored as cells suspension (with typical cell density of $\sim 7 \times 10^{3} \mathrm{CFU} \mathrm{ml}^{-1}$ ) in PBS with $5 \%$ glycerol at $-80^{\circ} \mathrm{C}$ to be used as inoculum. The strain T. versicolor ATCC 42530 (from American Type Culture Collection, Manassas, Virginia, USA) was maintained by sub-culturing it every $30 \mathrm{~d}$ on $20 \mathrm{~g} \mathrm{l}^{-1}$ malt extract agar $\left(15 \mathrm{~g} \mathrm{l}^{-1}\right)$ slants $(\mathrm{pH} 4.5)$ at $25^{\circ} \mathrm{C}$. A mycelial suspension of T. versicolor was prepared by homogenizing $5-7 \mathrm{~d}$ grown mycelium in malt extract medium (20 $\left.\mathrm{g} \mathrm{l}^{-1}, \mathrm{pH} 4.5\right)$ as described by Blánquez et al. (2004), and then stored in saline solution $\left(\mathrm{NaCl}-8 \mathrm{~g} \mathrm{l}^{-1}\right)$ at $4^{\circ} \mathrm{C}$ until use as inoculums (8.5 $\mathrm{g} \mathrm{l}^{-1}$ dry volatile solid mycelium).

\section{Laccase production}

Production of laccase by the four Streptomyces strains was done in ISP9 mineral medium (Shirling \& Gottlieb 1966) composed of (in g l$\left.{ }^{-1}\right):\left(\mathrm{NH}_{4}\right)_{2} \mathrm{SO}_{4}-2.64, \mathrm{KH}_{2} \mathrm{PO}_{4}$ anhydrous - 2.38, $\mathrm{K}_{2} \mathrm{HPO}_{4} \cdot 3 \mathrm{H}_{2} \mathrm{O}-5.65, \mathrm{MgSO}_{4}$. $7 \mathrm{H}_{2} \mathrm{O}-0.1$, with the following trace elements (in $\mathrm{mg} \mathrm{l}^{-1}$ ): $\mathrm{FeSO}_{4} \cdot 7 \mathrm{H}_{2} \mathrm{O}-1.1, \mathrm{ZnSO}_{4} \cdot 7 \mathrm{H}_{2} \mathrm{O}-1.5, \mathrm{CuSO}_{4} \cdot 5 \mathrm{H}_{2} \mathrm{O}-$ 6.4 and $\mathrm{MnCl}_{2} \cdot 4 \mathrm{H}_{2} \mathrm{O}-7.9$, pH 6.6 - 6.9. In this mineral medium, five different carbon sources were tested at $10 \mathrm{~g} \mathrm{l}^{-1}$ : soy flour, oat bran, glucose, wheat straw flour and spruce sawdust. Production of laccase activity by S. cyaneus was also tested in a modified and optimized ISP9 mineral medium, with 6.4 times less copper $\left(1 \mathrm{mg} \mathrm{l}^{-1} \mathrm{CuSO}_{4} \cdot 5 \mathrm{H}_{2} \mathrm{O}\right)$, and with the same five different carbon sources (at $10 \mathrm{~g} \mathrm{l}^{-1}$ ) except glucose, which was replaced by spelt flour.

Finally, to test the ability of $S$. cyaneus and T. versicolor to produce laccase activity in wastewater, secondary treated wastewater was collected (grab sample) at the Lausanne (Switzerland) municipal WWTP in the effluent of a moving bed bioreactor with full nitrification. The ionic wastewater composition, measured by ion chromatography-conductivity detector (Dionex DX 500), was (in $\mathrm{mg} \mathrm{l}^{-1}$ ): $\mathrm{P}_{-} \mathrm{PO}_{4}^{2-}-1.0$, $\mathrm{SO}_{4}^{2-}-229, \mathrm{Cl}^{-}-837, \mathrm{~N}-\mathrm{NO}_{3}^{-}-93, \mathrm{~N}-\mathrm{NH}_{4}^{+}-0.09$, $\mathrm{Mg}^{2+}-11.5, \mathrm{Ca}^{2+}-83, \mathrm{Na}^{+}-74, \mathrm{~K}^{+}-15.4$. In this wastewater, five different sources of carbon were tested: soy flour $\left(10 \mathrm{~g} \mathrm{l}^{-1}\right.$, initial $\mathrm{pH}$ after substrate addition: 6.8), spelt flour $\left(10 \mathrm{~g} \mathrm{l}^{-1}, \mathrm{pH} 7.1\right)$, rushes $\left(20 \mathrm{~g} \mathrm{l}^{-1}, \mathrm{pH}\right.$ 5.5), ash branches (100 $\left.\mathrm{g} \mathrm{l}^{-1}, \mathrm{pH} 4.8\right)$ and beech sawdust $\left(20 \mathrm{~g} \mathrm{l}^{-1}\right.$, $\mathrm{pH}$ 5.9).

The liquid media and the wastewater, together with their carbon sources, were autoclaved $30 \mathrm{~min}$ at $121^{\circ} \mathrm{C}$ and then inoculated with $0.33 \%$ or $0.67 \%(\mathrm{v} / \mathrm{v})$ of, respectively, Streptomyces and T. versicolor inocula. Cultures were incubated at $30^{\circ} \mathrm{C}$ for $23 \mathrm{~d}$ and shaken at $140 \mathrm{rpm}$ to ensure aerobic conditions. Every 1-3 d, $1.5 \mathrm{ml}$ was withdrawn in aseptic conditions from each culture flask and centrifuged at 10,000 $g$ for $20 \mathrm{~min}$. Cell-free culture supernatants were then used directly to determine laccase activity and $\mathrm{pH}$. At the end of the incubation period, cell-free supernatants from the remaining cultures showing the highest activity were collected with the same procedure, filtered at $0.45 \mu \mathrm{m}$ (Filtropur, Sarstedt), and stored at $-20^{\circ} \mathrm{C}$ until they were used as extracellular crude enzyme preparations.

\section{Concentrated S. cyaneus laccase preparation}

For micropollutant degradation and laccase stability assays, as laccase activity in the extracellular crude enzyme preparation was not always high enough, $100 \mathrm{ml}$ of cell-free culture supernatant of S. cyaneus (in modified ISP9 medium with soy flour), filtered at $0.45 \mu \mathrm{m}$, were concentrated 33 times by ultrafiltration (Vivaspin 20 centrifugation devices, PES membranes, MWCO: $30 \mathrm{kDa}$, from Startorius AG, Göttingen, Germany) to obtain $3 \mathrm{ml}$ of laccase concentrated at $\sim 2000 \mathrm{U} \mathrm{l}^{-1}$.

\section{Laccase activity test}

Laccase activity was determined using a colorimetric assay by measuring the oxidation of $0.5 \mathrm{mM}$ ABTS in oxygen-saturated acetate buffer $(0.1 \mathrm{M})$ at $\mathrm{pH} 4.5$ and $25^{\circ} \mathrm{C}$ as described by Margot et al. (2013b). Crude laccase preparation was added to the solution and the increase of absorbance at $420 \mathrm{~nm}$ was monitored with a temperaturecontrolled spectrophotometer (U-3010, Hitachi, Tokyo, Japan). One unit of activity (U) was defined by the oxidation of one $\mu \mathrm{mol}$ of ABTS per min, using the extinction coefficient $\varepsilon_{420 \mathrm{~nm}}$ of $36,000 \mathrm{M}^{-1} \mathrm{~cm}^{-1}$ (Childs \& Bardsley 1975).

The laccase ability to oxidize other substrates was determined by the same procedure, monitoring the oxidation at $468 \mathrm{~nm}\left(\varepsilon_{468 \mathrm{~nm}}: 27,500 \mathrm{M}^{-1} \mathrm{~cm}^{-1}\right)$ (Muñoz et al. 1997), $470 \mathrm{~nm}\left(\varepsilon_{470 \mathrm{~nm}}: 26,600 \mathrm{M}^{-1} \mathrm{~cm}^{-1}\right)$ (Koduri \& Tien 1995) and $526 \mathrm{~nm}\left(\varepsilon_{526 \mathrm{~nm}}: 65,000 \mathrm{M}^{-1} \mathrm{~cm}^{-1}\right)$ (Palmieri et al. 1997) for, respectively, 2,6-dimethoxyphenol (DMP, at 0.5 $\mathrm{mM}$ ), guaiacol (at $0.5 \mathrm{mM}$ ) and syringaldazine (at 0.01 $\mathrm{mM}$, stock solution of $0.216 \mathrm{mM}$ in methanol).

\section{Influence of the $\mathrm{pH}$ on laccase activity}

Laccase activity was measured at different $\mathrm{pH}$ values, from 2.6 to 8 , in citric acid $(2-40 \mathrm{mM})$ - dibasic sodium 
phosphate $(8-130 \mathrm{mM})$ buffers, with four different substrates: ABTS $(0.5 \mathrm{mM})$, DMP $(0.5 \mathrm{mM})$, syringaldazine $(0.01 \mathrm{mM})$ and guaiacol $(0.5 \mathrm{mM})$. Aliquots of $200 \mu \mathrm{l}$ of $S$. cyaneus crude laccase preparation $\left(\mathrm{L}_{S c}\right)$, or 30 to $200 \mu \mathrm{l}$ of T. versicolor commercial laccase solution $\left(\mathrm{L}_{T v}, 0.1 \mathrm{~g} \mathrm{l}^{-1}\right)$ were added to a total of $1200 \mu \mathrm{l}$ of reaction mixture, the activity of which was measured at $25^{\circ} \mathrm{C}$ as described above. The $\mathrm{pH}$ was measured in the solution after addition of the laccase preparation. Measurements were conducted in duplicate.

\section{Temperature influence on the activity}

Laccase activity was measured at different temperatures, from 10 to $80^{\circ} \mathrm{C}$, in acetate buffer $\left(0.1 \mathrm{M}, \mathrm{pH} 4.5\right.$ at $\left.25^{\circ} \mathrm{C}\right)$, with $0.5 \mathrm{mM}$ ABTS. Aliquots of 30 to $200 \mu \mathrm{l}$ of $S$. cyaneus crude laccase preparation, or $30 \mu \mathrm{l}$ of $T$. versicolor commercial laccase solution $\left(0.1 \mathrm{~g} \mathrm{l}^{-1}\right)$ were added to $1200 \mu \mathrm{l}$ of reaction mixture after which the activity was measured as described above. The temperature and $\mathrm{pH}$ were checked in the spectrophotometer cuvettes before and after the reaction. Measurements were conducted on 2 to 3 replicates. As the $\mathrm{pH}$ of the acetate buffer decreased when the temperature increased (Additional file 1: Figure S1, Supporting information (SI)), the measured activities were corrected to an equivalent activity at $\mathrm{pH} 4.5$, as described in the SI, section 1.

\section{Stability at different $\mathrm{pH}$}

Laccase stability was assessed in pure water, as well as in buffer solutions at different pH. Citric acid (5-20 mM) dibasic sodium phosphate $(10-40 \mathrm{mM})$ buffers were used for $\mathrm{pH} 3$ to 7 , and Tris - $\mathrm{HCl}$ buffers $(50 \mathrm{mM})$ for pH 8 and 9. Concentrated S. cyaneus crude laccase preparation or commercial $T$. versicolor laccase were added to the buffers to reach an initial laccase activity of $130 \mathrm{U} \mathrm{l}^{-1}$ and then incubated in the dark at $25^{\circ} \mathrm{C}$ for $55 \mathrm{~d}$. The laccase activity and the $\mathrm{pH}$ in the solutions were monitored regularly. Experiments were conducted in duplicate.

\section{Inhibition by sodium chloride}

The inhibitory effect of sodium chloride was assessed by measuring the laccase activity with ABTS in acetate buffer (0.1 M, pH 4.5) containing from 0 to $600 \mathrm{mM}\left(0-35 \mathrm{~g} \mathrm{l}^{-1}\right)$ of $\mathrm{NaCl}$. Crude S. cyaneus laccase preparation or commercial $T$. versicolor laccase were added to the solution (initial laccase activity without inhibitors of $10 \mathrm{U} \mathrm{l}^{-1}$ ), incubated for $30 \mathrm{~s}$, before measuring the activity with the addition of ABTS (0.5 mM).

\section{Micropollutant analysis}

Determination of BPA, DFC and MFA concentrations was carried out by reverse phase liquid chromatography with a diode-array detector (HPLC-DAD) (LC-2000plus, Jasco, Tokyo, Japan, equipped with Bondapack-C18 column,
15-20 $\mu \mathrm{m}, 3.9 \mathrm{~mm} \times 300 \mathrm{~mm}$, Waters ${ }^{\mathrm{TM}}$, Milford, USA) as described by Margot et al. (2013b). Briefly, separation of the compounds was conducted with a 20-min gradient, at $1 \mathrm{ml} \mathrm{min}{ }^{-1}$, of pure $\mathrm{H}_{2} \mathrm{O}$ containing $0.1 \%$ acetic acid and increasing concentration of methanol from 40 to $65 \%(\mathrm{v} / \mathrm{v})$. Detection of the compounds was done by DAD at 200, 224 and $278 \mathrm{~nm}$. The limit of detection (LOD) was around $0.3 \mathrm{mg} \mathrm{l}^{-1}(\sim 1 \mu \mathrm{M})$.

\section{Micropollutant oxidation assay with laccase at different $\mathrm{pH}$}

Micropollutant oxidation assays were performed as previously described by Margot et al. (2013b) in citrate phosphate buffer $(30-40 \mathrm{mM})$ at three different $\mathrm{pH}$ values (5, 6 and 7) with a mixture of the three compounds at $20 \mathrm{mg} \mathrm{l}^{-1}$ each: DFC, MFA and BPA. Relatively high concentrations were tested to use a fast and simple analytical method (HPLC-DAD). As the pollutant stock solutions were prepared in methanol or acetone, the reaction mixture contained at the end $4 \%(\mathrm{v} / \mathrm{v})$ of methanol and $2 \%$ of acetone, which did not significantly influence laccase activity. Batch reactions were conducted in 2-ml glass vials containing $1 \mathrm{ml}$ of oxygen-saturated reaction mixture. Reactions were initiated by adding laccase preparation to obtain an initial activity of $210-220 \mathrm{U}^{-1}$. For $T$. versicolor laccase, a stock solution of commercial enzyme ( $1 \mathrm{~g} \mathrm{l}^{-1}$ in pure water) was used. For S. cyaneus laccase, concentrated crude enzyme preparation (laccase activity of $2000 \mathrm{U} \mathrm{l}^{-1}$ ) was added. The vials were incubated in the dark at $25^{\circ} \mathrm{C}$ under static conditions for $12 \mathrm{~d}$. As shown in a previous study (Margot et al. 2013b), diffusion of oxygen from the air space was sufficient to maintain a high level of dissolved oxygen during the reaction. After defined reaction times, aliquots $(50 \mu \mathrm{l})$ were withdrawn from each vial and directly injected into the HPLC column to analyse micropollutant concentrations. Controls without laccase were performed at the three $\mathrm{pH}$ values to assess chemical degradation. Duplicate experiments were conducted. Laccase activity and $\mathrm{pH}$ were analysed at the beginning and at the end of the incubation period in each vial. The $\mathrm{pH}$ stayed stable during the experiments in all the vials.

\section{Results}

\section{Production of laccase activity by Streptomyces strains}

Among the four strains of Streptomyces tested in ISP9 medium, laccase activity was only detected in the culture supernatant of $S$. cyaneus (with soy flour: $35 \mathrm{U} \mathrm{l}^{-1}$, oat bran: $2.75 \mathrm{U} \mathrm{l}^{-1}$ and glucose: $3.75 \mathrm{U} \mathrm{l}^{-1}$ ) and $S$. ipomoea (with soy flour: $0.75 \mathrm{U} \mathrm{l}^{-1}$ and oat bran: $0.5 \mathrm{U} \mathrm{l}^{-1}$ ), despite notable growth of all four strains in the media containing soy flour and oat bran. No laccase activity was detected in the cultures of S. psammoticus and S. griseus, neither in ISP9 medium with the five different carbon sources, nor in another specific medium with wheat straw and yeast 
extract, as described by Niladevi and Prema (2008). The absence of activity with $S$. psammoticus strain MTCC 7334 contrasts with studies of Niladevi et al. (2008). Although S. griseus was reported to produce extracellular laccase, this enzyme is assumed to be mainly localized in the cell wall (Endo et al. 2002), which could explain the absence of activity detected in the culture supernatant. No activity was detected in any culture when wheat straw flour and spruce sawdust were used as the sole carbon source. Depending on the substrate, S. cyaneus produced from 5.5- to 46-times more laccase activity than S. ipomoea, making this strain the best candidate among the tested Streptomyces strains for laccase production during wastewater treatment. Thus, only S. cyaneus was selected for further characterization.

Laccase activity in the supernatant of $S$. cyaneus cultures was enhanced in modified ISP9 medium (containing 6.4 times less copper) (Figure 1a), reaching on average $57 \mathrm{U} \mathrm{l}^{-1}$ with soy flour and $30 \mathrm{U} \mathrm{l}^{-1}$ with spelt flour. Similar activities $\left(200 \mathrm{U} \mathrm{l}^{-1}\right.$ at $50^{\circ} \mathrm{C}$, equivalent to about $50 \mathrm{U} \mathrm{l}^{-1}$ at $25^{\circ} \mathrm{C}$ ) were measured with the same strain after $14 \mathrm{~d}$ of growth with soy flour by Moya et al. (2010). The activity increased rapidly after 4-5 d of incubation, once the strain had reached the stationary phase (Additional file 1: Figure S2, SI). Similar observations were made by Arias et al. (2003), who suggested that this increase in activity was related to cell death and lysis releasing intracellular laccase. After 8-9 $\mathrm{d}$ of incubation, laccase production decreased and the activity reached a plateau, staying at a similar level until the end of the incubation $(23 \mathrm{~d})$.

\section{Laccase production in treated wastewater}

Both $S$. cyaneus and $T$. versicolor were able to grow in sterile secondary treated wastewater containing different carbon sources. In S. cyaneus culture supernatant (Figure 1b), laccase activity was observed with soy flour (with a similar level to that in ISP9 medium but delayed by 2 weeks) and spelt flour (10 times lower than in ISP9), but also with rushes $\left(6.6 \mathrm{U} \mathrm{l}^{-1}\right)$, suggesting that lignocellulose-containing waste could serve as substrate for laccase production. However, no or only very low activity levels $\left(<1 \mathrm{U} \mathrm{l}^{-1}\right)$ were observed with wood branches or sawdust, possibly due to the low $\mathrm{pH}$ (4.7) present in the wood medium and probable lack of essential nutrients (nitrogen and phosphorus) with sawdust as the sole substrate.

Laccase activity of $T$. versicolor cultures in wastewater increased very rapidly after only 2-3 d of incubation (Figure 1c), reaching a maximum of 508, 778 and $945 \mathrm{U}$ $\mathrm{l}^{-1}$ for spelt flour, soy flour and wood branches, respectively. Lower activity was observed with rushes $\left(151 \mathrm{U} \mathrm{l}^{-1}\right)$ and sawdust $\left(79 \mathrm{U} \mathrm{l}^{-1}\right)$ but, unlike S. cyaneus, all lignocellulose substrates led to the presence of laccase activity in culture supernatant. High activity (e.g., $550 \mathrm{U} \mathrm{l}^{-1}$ with wood branches and soy flour) was still measured after 45 $\mathrm{d}$ of incubation (data not shown), showing the ability of this fungus to survive in the long term on these lignocellulosic substrates. Laccase activity was 20-times higher in $T$. versicolor culture supernatant with soy flour and rushes than for S. cyaneus, and 175-times higher with spelt flour. Wood branches were the best substrate for $T$. versicolor laccase production.

T. versicolor produces two main laccase isoenzymes, the proportions of which differ depending on the growth substrate or the presence of inductors (Bourbonnais et al. 1995; Moldes et al. 2004; Nakatani et al. 2010). As the kinetic properties of these two main isoenzymes differ slightly (Bourbonnais et al. 1995; Moldes \& Sanromán 2006), different proportions of isoenzymes in the mixture can lead to slightly different oxidation behavior. The commercially available preparation which is a mixture of different proteins with at least two distinct enzymes displaying laccase activity (Additional file 1: Figure S3, SI) had very similar micropollutant oxidation activity as the laccase produced by $T$. versicolor on wood substrate (Additional file 1: Figure S4, SI). Thus, to allow comparison with literature data and to have a reproducible and constant

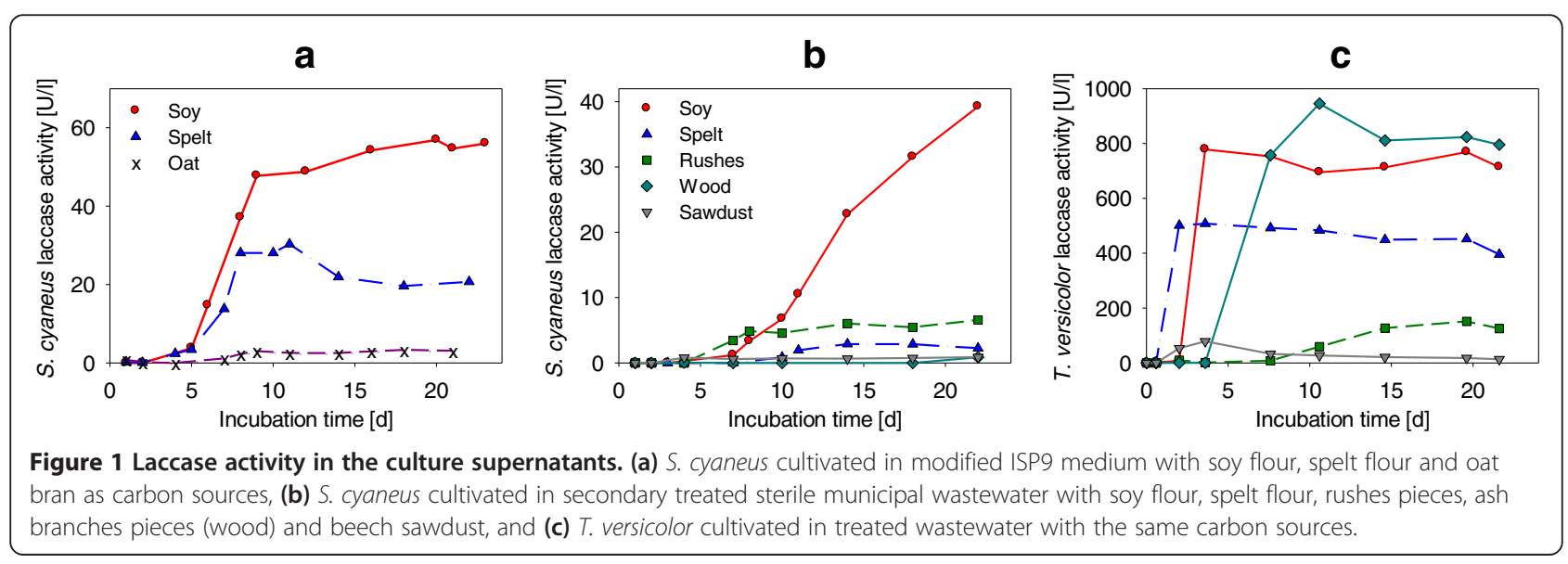


proportion of the different laccase isoenzymes, commercial T. versicolor laccase preparation was used for the following experiments instead of culture supernatants.

\section{Influence of $\mathrm{pH}$ on laccase activity with different substrates}

As shown in Figure 2, laccase preparations of S. cyaneus $\left(\mathrm{L}_{S c}\right.$, from the culture supernatants) and commercial laccase of $T$. versicolor $\left(\mathrm{L}_{T v}\right)$ were both able to oxidize the four substrates tested, as also observed in other studies (Arias et al. 2003; Eichlerová et al. 2012). Compared to its activity with ABTS at pH 4.5 (close to the optimum), $\mathrm{L}_{S c}$ was 4-, 10- and 46-times less active with DMP, syringaldazine and guaiacol, respectively. $\mathrm{L}_{T v}$ was only 1.3-, 2- and 12-times less active with these three substrates compared to ABTS, showing a broader substrate specifity than $\mathrm{L}_{S c}$.

For the four laccase substrates, the $\mathrm{pH}$ had a very strong influence on the activity of both laccase preparations, with very low activity in slightly alkaline conditions $(\mathrm{pH}>7)$ and maximum activity between $\mathrm{pH} 4$ and 4.5 for $\mathrm{L}_{S c}$, and from less than 2.7 to 5 for $\mathrm{L}_{T v}$ (Figure 2). $\mathrm{L}_{S c}$ activity was strongly dependent on the $\mathrm{pH}$, with, for instance, an order of magnitude increase between $\mathrm{pH} 5.5$ and 4.5 with ABTS (from 8.4 to $87 \mathrm{U} \mathrm{l}^{-1}$ ) and with syringaldazine (from 0.8 to $9 \mathrm{U} \mathrm{l}^{-1}$ ), and a rapid decrease of activity below pH 3.5 with all substrates.

\section{Influence of temperature on laccase activity}

Maximum activities (with ABTS, $\mathrm{pH} 4.5$ ) were observed at $60^{\circ} \mathrm{C}$ and $50^{\circ} \mathrm{C}$ for $\mathrm{L}_{S c}$ and $\mathrm{L}_{T v}$, respectively (Figure 3a), which is $10^{\circ} \mathrm{C}$ lower than optimal temperatures reported in other studies $\left(70^{\circ} \mathrm{C}\right.$ and $60^{\circ} \mathrm{C}$ respectively) (Arias et al. 2003; Rancaño et al. 2003). A rapid decrease in activity was observed above $70^{\circ} \mathrm{C}$ for both preparations, probably due to heat denaturation of the enzymes. For $\mathrm{L}_{S c}$, a rapid decrease in activity was also observed when the temperature decreased below $50^{\circ} \mathrm{C}$, with only $25 \%$ of its maximum activity remaining at $25^{\circ} \mathrm{C}$, compared to $73 \%$ for $\mathrm{L}_{T v}$. Both laccase preparations were still active at $10^{\circ} \mathrm{C}$, showing 13 and $44 \%$ of their maximum activity for $\mathrm{L}_{S c}$ and $\mathrm{L}_{T v}$, respectively.

\section{Inhibition of the laccase activity by $\mathrm{NaCl}$}

Both laccase preparations were sensitive to sodium chloride (Figure $3 \mathrm{~b}$ ), with, for $\mathrm{L}_{S c}$ and $\mathrm{L}_{T v}$ respectively, 4 and $20 \%$ of activity inhibition at $5 \mathrm{mM}$, a typical concentration for municipal wastewater, and more than 80 and $90 \%$ at
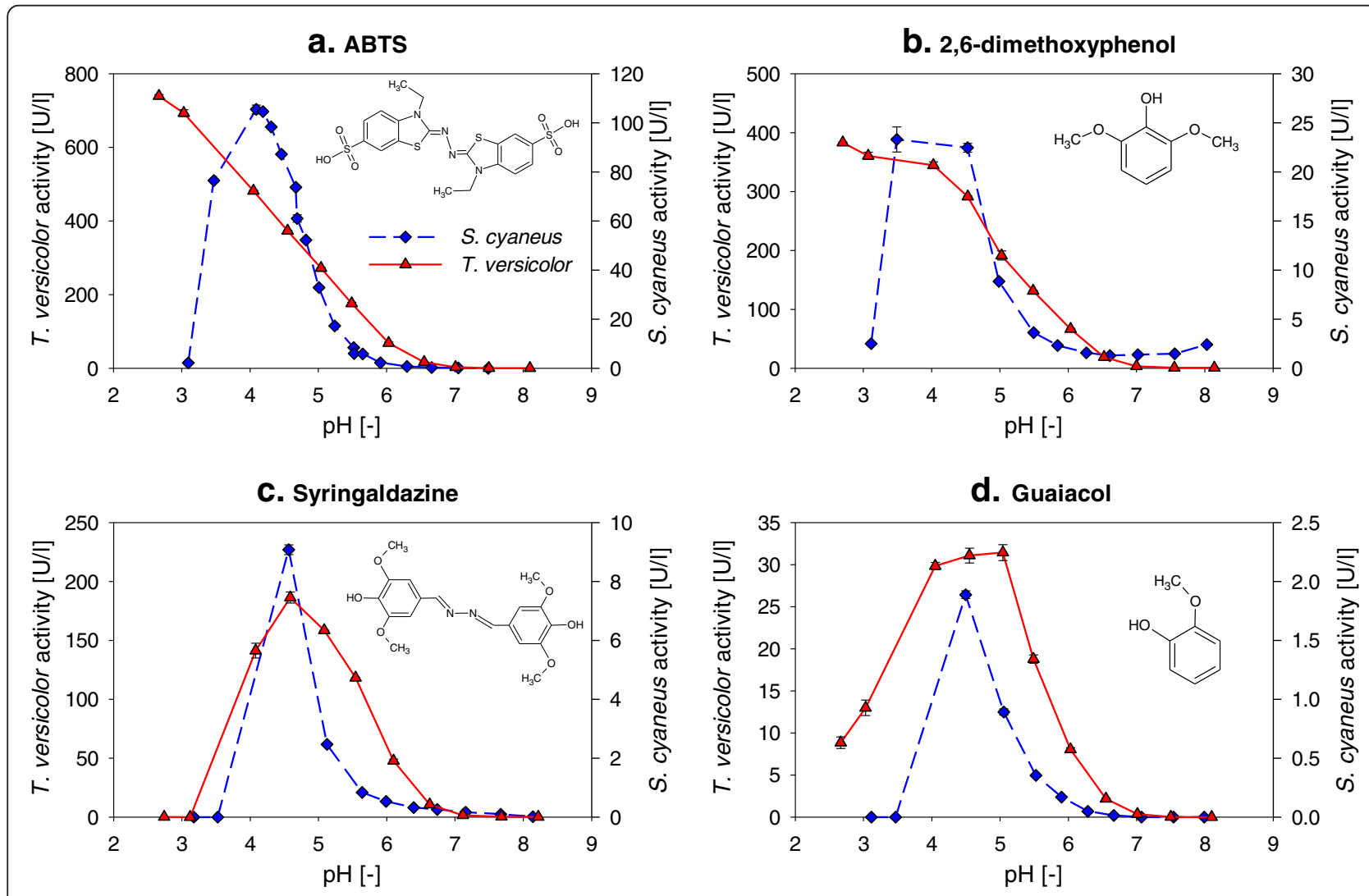

Figure 2 Influence of pH on S. cyaneus ( $\downarrow$ ) and T. versicolor ( $\mathbf{\Delta}$ ) laccase activity with different substrates: (a) ABTS, (b) 2,6-dimethoxyphenol, (c) syringaldazine and (d) guaiacol. Average and values of duplicates, at $25^{\circ} \mathrm{C}$. 


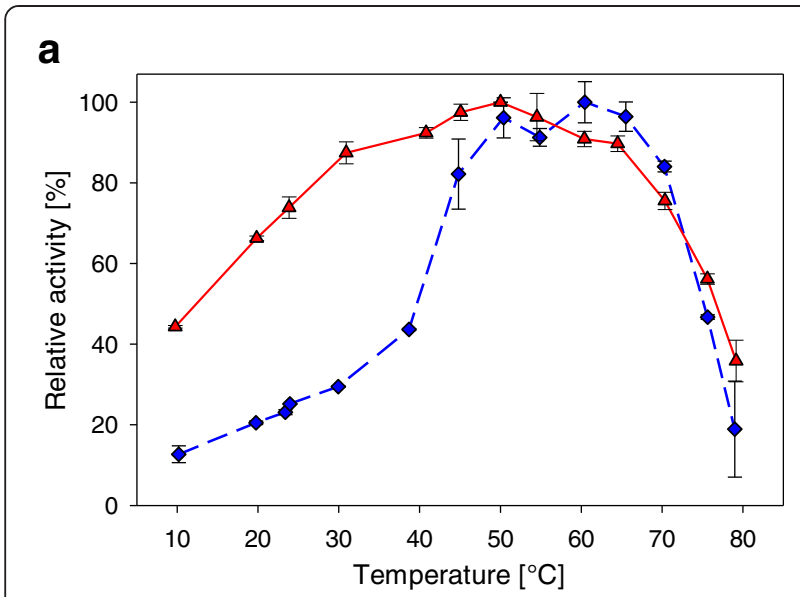

b

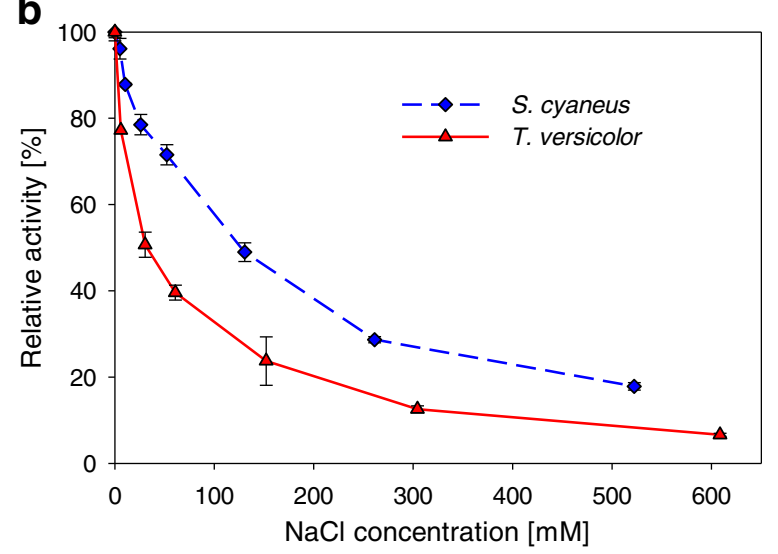

Figure 3 Influence of temperature (a) and sodium chloride concentration (b) on S. cyaneus ( $\downarrow$ ) and $T$. versicolor $(\boldsymbol{\Delta})$ laccase activity. Average \pm standard deviation of 2 to 3 replicates, at pH 4.5 . Inhibition experiments with $\mathrm{NaCl}$ were performed at $25^{\circ} \mathrm{C}$, with an initial laccase activity (without $\mathrm{NaCl}$ ) of $10 \mathrm{U} \mathrm{I}^{-1}$.

$550 \mathrm{mM}$, a concentration found in various industrial wastewaters and in seawater (Lefebvre \& Moletta 2006; Leutz 1974). The $\mathrm{IC}_{50}$ (inhibition concentration for which the activity was reduced by $50 \%$ ) was observed at $130 \mathrm{mM}$ for $\mathrm{L}_{S c}$ and at $30 \mathrm{mM}$ for $\mathrm{L}_{T v}$, showing the higher sensitivity of the latter towards chloride ions. Similar $\mathrm{IC}_{50}$ (around $20 \mathrm{mM} \mathrm{Cl}^{-}$) were observed for $\mathrm{L}_{T v}$ by Enaud et al. (2011), but no information on $\mathrm{L}_{S c}$ chloride inhibition was reported previously.

\section{Stability of laccase at different $\mathrm{pH}$}

The stability of laccase incubated at different $\mathrm{pH}$ and $25^{\circ} \mathrm{C}$ is presented in Figure 4. The data were fitted with a biexponential equation to model various mechanisms of enzyme inactivation (Aymard \& Belarbi 2000), as described in the SI, section 2 . The results of the fitting and the estimated half-life of laccase at different $\mathrm{pH}$ are presented in Additional file 1: Table S1 (SI). In most cases, a fast initial inactivation rate, represented by a high apparent first-order rate constant $\left(k_{2}\right)$, followed by slower decay kinetics $\left(k_{1}\right)$ were observed.

$\mathrm{L}_{T v}$ was more stable than $\mathrm{L}_{S c}$ in acidic and neutral $\mathrm{pH}$. Very fast inactivation of $\mathrm{L}_{S c}$ was observed at $\mathrm{pH} 3$, with a half-life shorter than 3 min compared to $11 \mathrm{~h}$ for $\mathrm{L}_{T v}$. At this $\mathrm{pH}$, instant precipitation appeared when $\mathrm{L}_{S c}$ was added. At $\mathrm{pH} 4$, no precipitate was visible, but $\mathrm{L}_{S c}$ was still rapidly inactivated, with a half-life of $90 \mathrm{~min} . \mathrm{L}_{S c}$ and $\mathrm{L}_{T v}$ stability increased as the $\mathrm{pH}$ increased, reaching the highest stability at $\mathrm{pH} 9$ for $\mathrm{L}_{S c}$, with an estimated half-life of $82 \mathrm{~d}$, and at $\mathrm{pH} 7-8$ for $\mathrm{L}_{T v}$, with a half-life of 47 d. When laccase was incubated in pure water $(\mathrm{pH} 6.5-7.5)$, the stability was significantly reduced compared to storage in a buffer at neutral $\mathrm{pH}$; with half-life of only 3 and $6 \mathrm{~d}$ for $\mathrm{L}_{S c}$ and $\mathrm{L}_{T v}$, respectively.

From pH 5 to 8 , an increase in $\mathrm{L}_{T v}$ activity was observed during the first $24 \mathrm{~h}$ of incubation, as illustrated for $\mathrm{pH} 6$ in Figure 4d. At pH 6 and 7, this increase in activity was as high as $34 \%$. A similar increase in activity $(24 \pm 1 \%)$ was also observed after sonication (15 pulses of $3 \mathrm{~s}$ at $100 \mathrm{~W}$ ) of fresh laccase solutions, suggesting that this increase was due to a better dispersion of the enzymes that were initially partly aggregated (presence of particles with strong laccase activity). This phenomenon was also noticed in other studies (Margot et al. 2013b; Silvério et al. 2013). Changes of the storage conditions ( $\mathrm{pH}$ and temperature) could also gradually influence laccase activity, possibly due to slow reorganisation of laccase structure or conformation (Kurniawati \& Nicell 2008).

As the tests were not conducted in sterile conditions, bacterial growth (turbidity, confirmed by microscopy) was observed after $2 \mathrm{~d}$ in the incubation tubes containing $\mathrm{L}_{S c}$ at $\mathrm{pH} 4$ to 7 , resulting in an increase in the $\mathrm{pH}$ to 7.3-7.7 in all these tubes (Additional file 1: Figure S5, SI). An increase in activity following the increase in $\mathrm{pH}$ was observed (Figure 4b-e), suggesting a partially reversible $\mathrm{pH}$ inactivation of the enzyme. To verify this hypothesis, $\mathrm{L}_{S c}$ and $\mathrm{L}_{T v}$ were again incubated at $\mathrm{pH} 3.5$ and 3, respectively, and their residual activity was followed over time. At a certain time, the $\mathrm{pH}$ of the solution of two of the four replicates was increased to 7.5 by addition of concentrated $\mathrm{NaOH}$. The effect of this artificial increase in $\mathrm{pH}$ on laccase stability is presented in Figure 5. For $\mathrm{L}_{S c}$, as expected, a very fast inactivation was observed in the four replicates, with more than $90 \%$ of inactivation within $1 \mathrm{~h}$ (Figure 5a). However, when the $\mathrm{pH}$ was increased to 7.5 after $3 \mathrm{~h}$ of incubation at $\mathrm{pH} 3.5, \mathrm{~L}_{S c}$ activity increased again, reaching $86 \%$ of the initial activity after $4 \mathrm{~d}$. At the same time, the precipitate observed at $\mathrm{pH} 3.5$ was again solubilised at $\mathrm{pH}$ 7.5. In the replicates maintained at $\mathrm{pH} 3.5$, the activity reduced to an undetectable level after $1 \mathrm{~d}$. After $2 \mathrm{~d}$ at $\mathrm{pH}$ $3.5, \mathrm{pH}$ was increased to 7.5 in one replicate, leading to a slow $\mathrm{L}_{S c}$ activity increase from the no-detect level to $10 \%$ of the initial activity. These results indicate that $\mathrm{L}_{S c}$ is 


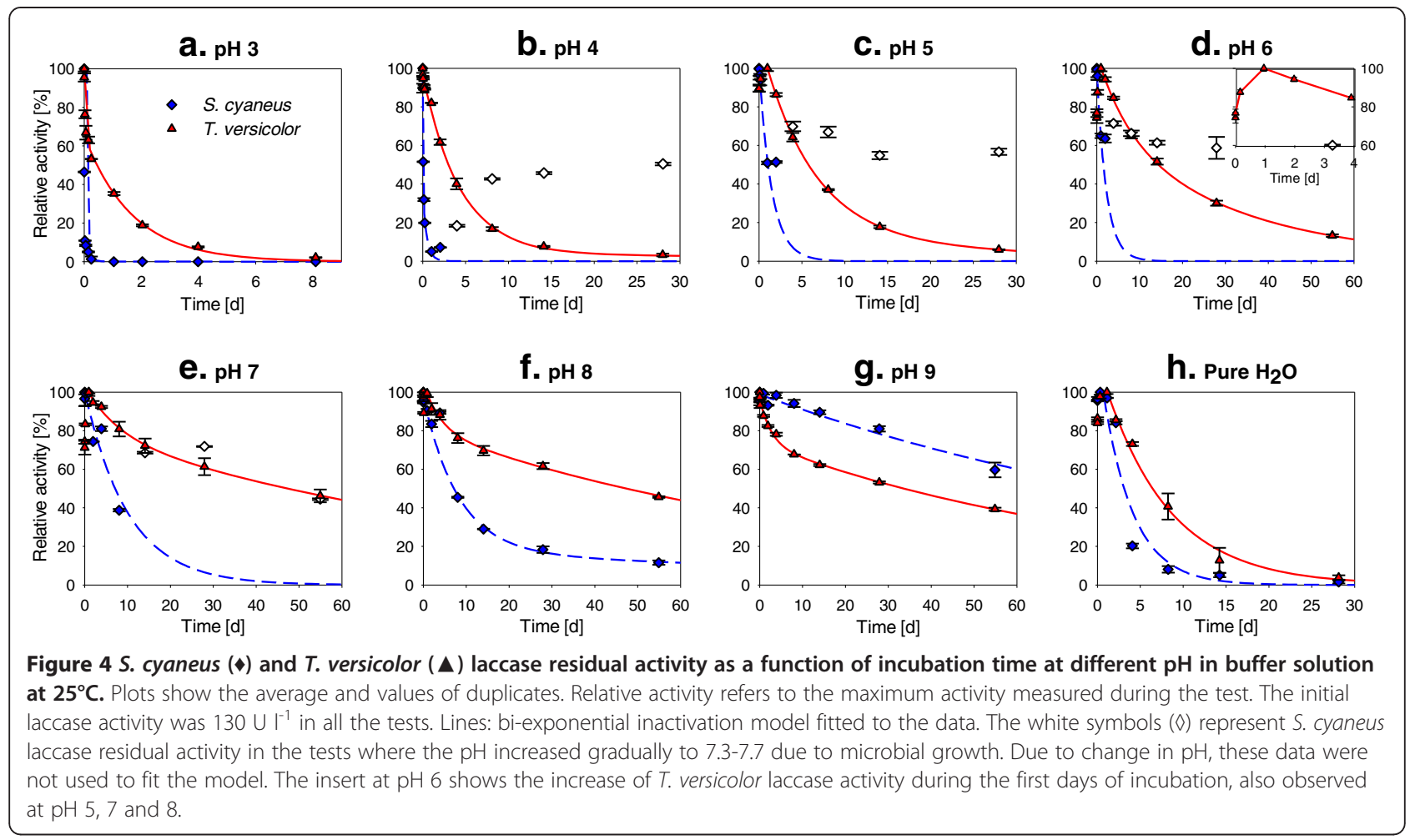

affected by two inactivation types, one that is fast but reversible and another that is slower but irreversible. The former type is exactly what was observed in the stability experiment (depicted in Figure 4, b-e) when the $\mathrm{pH}$ increased due to bacterial activity. The irreversible $\mathrm{L}_{S c}$ inactivation seemed to be relatively similar to $\mathrm{L}_{T v}$ inactivation (Figure 4e), which seemed to be only affected by $\mathrm{pH}$ in an irreversible manner (Figure $5 b$ ).

\section{Micropollutant oxidation by laccase preparations}

The kinetics of laccase-mediated degradation of the plastic additive BPA and the two anti-inflammatory drugs DFC and MFA at different $\mathrm{pH}$ are presented in Figure 6. The residual concentrations were fitted with a variable order reaction model (Margot et al. 2013b) as described in the section 3 of the SI. The results of the fitting and the estimated half-life of the pollutants at different $\mathrm{pH}$ are presented in Additional file 1: Table S2 (SI).

Both laccase preparations were able to oxidize the three pollutants at all $\mathrm{pH}$ values studied. Except for BPA at $\mathrm{pH} 5$, where both laccases had a very similar efficiency, $\mathrm{L}_{T v}$ provided more efficient micropollutant oxidation, especially at $\mathrm{pH} 6$ and 7. As observed previously (Margot et al. 2013b), MFA was degraded in the control without laccase under acidic conditions, with a half-life of $1 \mathrm{~h}$ at $\mathrm{pH} 5$ and $9 \mathrm{~d}$ at $\mathrm{pH} 6$. Thus, at $\mathrm{pH} 5$, it was difficult to distinguish between laccase oxidation and abiotic degradation. However, at pH 6 and 7, MFA was significantly oxidized by both laccases. The highest oxidation rates of
BPA and DFC were observed at $\mathrm{pH} 6$ for $\mathrm{L}_{T w}$, with half-lives of $9 \mathrm{~min}$ and $2.2 \mathrm{~h}$, respectively, and at $\mathrm{pH} 5$ for $\mathrm{L}_{S c}$ with half-lives of $5.2 \mathrm{~h}$ and $32 \mathrm{~h}$, respectively.

The residual laccase activities in the reaction mixtures at the end of the test, after $12 \mathrm{~d}$ of incubation, are presented in Table 1. Loss of $97 \%$ of the initial activity was observed at $\mathrm{pH} 5$ for $\mathrm{L}_{T v}$. Additional laccase inactivation (from 0 to $17 \%$ ) seemed to occur over the course of the reaction, especially at $\mathrm{pH} 5$, compared to incubation in solutions without micropollutants (stability test). Unlike what was observed for oxidation of phenols (Kurniawati \& Nicell 2008), the laccase inactivation due to the catalytic reaction was, however, much lower than the inactivation due the test conditions ( $\mathrm{pH}$ and temperature). At the end of the test, $\mathrm{L}_{T v}$ activity was 17-times higher in the mixture at $\mathrm{pH} 6$ than at $\mathrm{pH} 5$. The residual activity of $\mathrm{L}_{S c}$ was slightly higher than that for $\mathrm{L}_{T v}$. This contrasts with the results of the stability test, where $\mathrm{L}_{S c}$ was rapidly, but reversibly, inactivated at these $\mathrm{pH}$ values.

\section{Discussion}

For selection of microorganisms able to produce laccase on-site for treating micropollutants in wastewater, the potential of four strains of Streptomyces bacteria together with the white-rot fungus $T$. versicolor was assessed for (i) their ability to produce laccase in treated wastewater on cheap substrates, (ii) their laccase activity at different $\mathrm{pH}$ and temperature, (iii) laccase inhibition by chloride salt, (iv) 


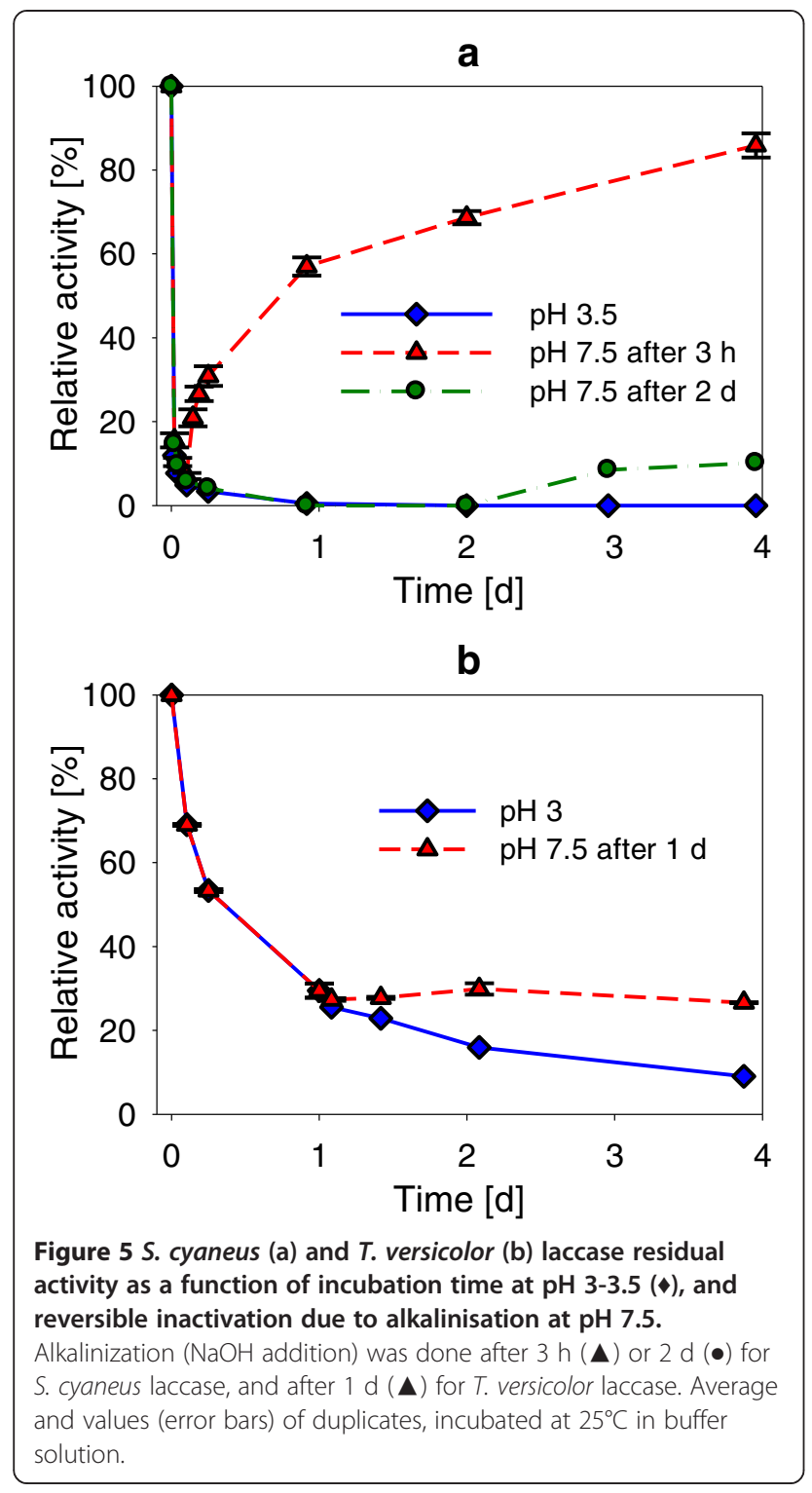

laccase stability, and (v) the laccase substrate range and their ability to oxidize different micropollutants.

\section{Laccase production on different substrates}

Among the four Streptomyces strains assessed, only $S$. cyaneus produced laccase to a level potentially sufficient for the targeted application, for instance in a system with a long hydraulic residence time (of a few days to a few weeks such as wetlands). Despite the attractive possibility of producing (low amounts of) laccase in treated wastewater on lignocellulosic substrates (rushes) with $S$. cyaneus without the addition of other nutrients, the activity levels reached were not comparable with those obtained in $T$. versicolor cultures (which were more than 20-times higher). T. versicolor was found to produce high amounts of laccase (up to $945 \mathrm{U} \mathrm{l}^{-1}$ ) in treated wastewater with ash branches (including the bark) as the sole substrate, which is promising for the development of a fungal trickling filter for wastewater post-treatment. Indeed, this forestry waste is cheap and widely available in Switzerland, for example, and the activity reached in the supernatant is high enough - according to a previous study (Margot et al. $2013 \mathrm{~b})$ - to allow high removal (>90\%) of various micropollutants (BPA, DFC, MFA and triclosan) in an appropriate time range (less than $10 \mathrm{~h}$ ) at $\mathrm{pH} 7$ and $25^{\circ} \mathrm{C}$, conditions that are found in municipal wastewaters. Maintaining T. versicolor in unsterile biologically treated wastewater is, however, still a challenge due to competition/predation by other microorganisms. This competition can probably be limited in case of use of lignocellulosic materials as the sole substrate, as only few organisms can use them as carbon source.

The composition of the growth substrate had a strong influence on laccase production by $T$. versicolor, as also observed in other studies on lignocellulosic materials (Özşölen et al. 2010). As only complex substrates were used here (wood with bark, integral soy flour, etc.), it was not possible to identify which components induced laccase production. It seemed that the role of wood bark was significant as much lower activity $\left(79 \mathrm{U} \mathrm{l}^{-1}\right)$ was observed in $T$. versicolor cultures with only beech sawdust compared to that with ash branches (with the bark). These results were also confirmed by an additional experiment in treated wastewater (Additional file 1: Figure S6, SI), where high $T$. versicolor laccase activity $\left(>550 \mathrm{U} \mathrm{l}^{-1}\right.$ ) was observed in culture supernatant after $9 \mathrm{~d}$ of cultivation on poplar (Populus spp.) branches with the bark, on reed pieces (Phragmites australis) and on wheat straw, and low activity $\left(<30 \mathrm{U} \mathrm{l}^{-1}\right)$ on pine wood chips (without bark) and glucose. Bark contains in general more lignin and polyphenols than wood (Harkin \& Rowe 1971), and aromatic or phenolic compounds related to lignin or lignin derivatives such as ferulic acid or vanillin, are known to induce laccase production by white-rot fungi (De Souza et al. 2004; Parenti et al. 2013). For S. cyaneus, induction of laccase production on lignocellulosic substrate was not observed. The role of laccase in Streptomyces spp. is, however, not clear and might be related more to morphogenesis than to lignin degradation (Endo et al. 2002). This is also supported by the means by which $S$. cyaneus likely produces extracellular laccase (cell lysis rather than active secretion). Indeed, the S. cyaneus laccase sequence deposited by Moya and co-workers (GenBank HQ857207) does not harbor any secretion signal peptide (J. Maillard, unpublished data).

Laccase activity at different $\mathrm{pH}$ values and temperatures Both laccases had optimal activity under acidic conditions $(\mathrm{pH}<5)$ for all substrates. Slight variations of the optimal $\mathrm{pH}(<3$ to 5$)$ were observed for the phenolic substrates, 


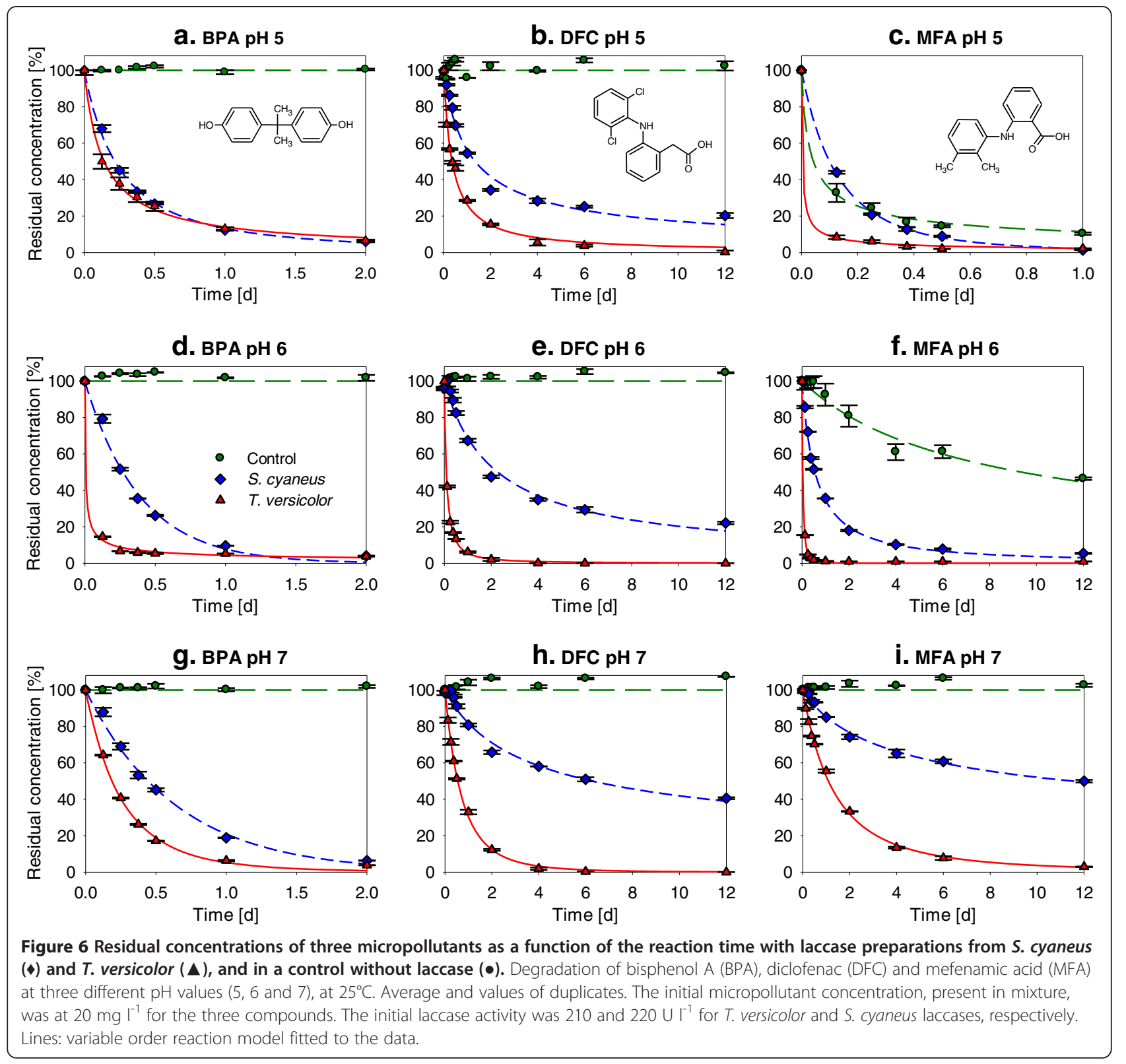

Table 1 Residual laccase activity in the reaction vials after $12 \mathrm{~d}$ of reaction with the mixture of micropollutants at $25^{\circ} \mathrm{C}$ and at different $\mathrm{pH}$

\begin{tabular}{cccc}
\hline & \multicolumn{2}{c}{ Residual activity $^{\mathbf{a}}$} & \multicolumn{2}{c}{ Residual predicted activity $^{\mathbf{b}}$} \\
\hline & T. versicolor & S. cyaneus & T. versicolor \\
& {$[\%]$} & {$[\%]$} & {$[\%]$} \\
$\mathrm{pH} 5$ & $3.3( \pm 0.2)$ & $10.4( \pm 0.2)$ & 20 \\
$\mathrm{pH} 6$ & $53.7( \pm 0.9)$ & $52.0( \pm 2.1)$ & 53 \\
$\mathrm{pH} \mathrm{7}$ & $68.4( \pm 1.0)$ & $79.1( \pm 0.1)$ & 74 \\
\hline
\end{tabular}

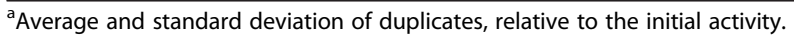
${ }^{\mathrm{b}}$ Residual activity after $12 \mathrm{~d}$ predicted with the bi-exponential model based on the stability test (incubation at $25^{\circ} \mathrm{C}$ at the same $\mathrm{pH}$ but without micropollutants). which are assumed to be related to the protonation/ deprotonation state of the compound (Rosado et al. 2012). The $\mathrm{pH}$ range in which significant activity was measured was wider for $\mathrm{L}_{T V}$ than for $\mathrm{L}_{S c}$, with $\mathrm{L}_{T V}$ showing higher activity in the $\mathrm{pH}$ range 5.5 to 7 . Both laccases showed, however, rather low activity under slightly alkaline conditions, impairing their use in non-acidified municipal wastewater ( $\mathrm{pH} 7-8)$.

The strong $\mathrm{pH}$ influence observed on the activity of both laccases on all the substrates could be related to a balance between two opposing phenomena (Xu 1997): (i) the increase in redox potential difference (and thus oxidation rate) between laccase type 1 copper site ( $\mathrm{T} 1$, where the substrate oxidation takes place) and the phenolic or 
aniline substrates when the $\mathrm{pH}$ increases, and (ii) the increase in hydroxyl inhibition of laccase (binding of the hydroxide anion to the T2/T3 $\mathrm{Cu}$, where the reduction of oxygen to water take place) at higher $\mathrm{pH}$, possibly leading to a bell-shape activity profile. Despite their relatively low amino acid sequence homology (Additional file 1: Figure S7, SI), similar mechanisms are expected for both laccases as the three-dimensional structure of the active site of S. cyaneus laccase is presumably very similar to the one of $T$. versicolor laccase (see sections 9 and 10 of the SI for details). This bell-shape profile was observed for both laccases on the phenolic substrates syringaldazine and guaiacol, but not on ABTS with $\mathrm{L}_{T v}$, which is consistent with the fact that the redox potential of ABTS is not dependent on the $\mathrm{pH}$ in the range tested (no protons involved in the oxidation) (Xu 1997). Due to its phenolic structure, a bell-shape profile was expected for DMP, but not observed with $\mathrm{L}_{T v}$. The increase of activity with the $\mathrm{pH}$ was, however, possibly out of the $\mathrm{pH}$ range studied (appearing at lower $\mathrm{pH}$ ). The low $\mathrm{L}_{S c}$ activity below $\mathrm{pH} 3.5$ with all substrates was probably due to the fast inactivation of the enzyme at these $\mathrm{pH}$ values (50\% inactivation in 2 min at $\mathrm{pH} 3$ ) than due to thermodynamic and kinetic considerations (variation of redox potential).

Both laccases had optimal activity on ABTS at 50 to $60^{\circ} \mathrm{C}$. These optimal temperatures can, however, differ depending on the substrate (Margot et al. 2013b; Yang et al. 2013). $\mathrm{L}_{T v}$ showed significant activity in a wider temperature range than $\mathrm{L}_{S c}$, especially at lower temperatures (from 10 to $40^{\circ} \mathrm{C}$ ). It retained $44 \%$ of its maximum activity at $10^{\circ} \mathrm{C}$, making this enzyme more attractive for municipal wastewater treatment $\left(10-25^{\circ} \mathrm{C}\right)$.

\section{Laccase inhibition by chloride}

Municipal and especially industrial wastewaters can contain relatively high chloride concentrations. Chloride $\left(\mathrm{Cl}^{-}\right)$, similar to other halide anions $\left(\mathrm{F}^{-}, \mathrm{Br}^{-}\right)$or to the hydroxide anion $\left(\mathrm{OH}^{-}\right)$, has been reported to either bind to the $\mathrm{T} 2 \mathrm{Cu}$ of laccase and to interrupt the internal electron transfer between $\mathrm{T} 1$ and $\mathrm{T} 2 / \mathrm{T} 3$ active site (Xu 1996), and/or to bind near the T1 active site, blocking the access of the substrate to $\mathrm{T} 1 \mathrm{Cu}$ or inhibiting the electron transfer (Enaud et al. 2011). Both laccases considered here were inhibited by sodium chloride, with $\mathrm{L}_{S c}$ being slightly more tolerant. The chloride concentration in municipal wastewater which is around 2.5 to $5 \mathrm{mM}$ (unpublished data, Lausanne WWTP), is not expected to affect laccase activity significantly $(<20 \%)$. However, chloride inhibition can be an issue for the treatment of industrial effluents from, for example, the pharmaceutical industry (around $90 \mathrm{mM}$ $\mathrm{Cl}^{-}$(Rajkumar \& Palanivelu 2004)), especially for $\mathrm{L}_{T v}$ (> 60\% inhibition).

\section{Laccase stability}

For all biotechnological applications, good stability of the enzyme under the treatment conditions is required. Enzyme inactivation is influenced by many different factors, the $\mathrm{pH}$ being an important one due to its effect on the structures of proteins (influence on the balance of electrostatic and hydrogen bonds between the amino acids) (Sadana 1988). $\mathrm{L}_{S c}$ incubated at $25^{\circ} \mathrm{C}$ in buffer solutions was relatively rapidly inactivated $\left(\mathrm{t}_{1 / 2}: 0-2 \mathrm{~d}\right)$ at acidic $\mathrm{pH}$ $(<7)$ compared to $\mathrm{L}_{T v}$. However, this fast inactivation was reversible and $\mathrm{L}_{S c}$ could recover most of its activity when the $\mathrm{pH}$ was switched again to alkaline conditions. The mechanism of this reversible $\mathrm{pH}$ inactivation is unknown, but could be due to refolding of the tertiary structure of the enzyme when the $\mathrm{pH}$ increases (Kurniawati \& Nicell 2008), or possibly resolubilization of precipitated laccase. The irreversible $\mathrm{L}_{S c} \mathrm{pH}$ inactivation seemed to be in the same range as that observed for $\mathrm{L}_{T v}$. Thus, if the reversible $\mathrm{pH}$ inactivation can be avoided, both laccases would have relatively similar stability. This was observed during the micropollutant degradation test. Indeed, the $12 \mathrm{~d}$ stability of $\mathrm{L}_{S c}$ at $\mathrm{pH} 5,6$ and 7 during this test was similar or even higher than that of $\mathrm{L}_{T v}$, and much higher than what was observed for $\mathrm{L}_{S c}$ during the stability test. This suggests that the different incubation conditions, such as the presence of micropollutants (laccase substrate) and solvents (4\% methanol and $2 \%$ acetone), prevented the reversible inactivation, possibly by limiting $\mathrm{L}_{S c}$ precipitation/ aggregation or by increasing the stability due to pollutant binding to the active centre of the enzyme (Mai et al. 2000). Laccase stability is thus not only dependent on the $\mathrm{pH}$ but also on the composition of the solution. This was also confirmed by the much higher laccase stability in buffer solution at $\mathrm{pH} 7$ than in pure water at the same $\mathrm{pH}$.

Similar stability results for $\mathrm{L}_{T v}$, were previously reported (Kurniawati \& Nicell 2008; Mai et al. 2000). In most cases, a fast initial inactivation rate followed by slower decay kinetics was observed. Some authors explained this behavior by the possible presence of two isoenzymes of laccase, one being unstable and rapidly inactivated and the other being more stable (Kurniawati \& Nicell 2008). However, other mechanisms may also explain this biphasic behavior (Aymard \& Belarbi 2000), such as a fast reversible inactivation followed by a slower irreversible one. T. versicolor is known to produce at least four different isoenzymes, which can differ significantly in their stability (Koschorreck et al. 2008). The commercially available T. versicolor laccase preparation used in this study contains, as shown in Additional file 1: Figure S3, SI, at least two distinct enzymes with laccase activity, possibly explaining the observed biphasic behavior. As the proportion of the different isoenzymes is reported to be influenced by the culture conditions (Moldes et al. 2004), stability may differ for other 
sources of $T$. versicolor laccase. The higher and relatively good laccase stability observed at neutral to alkaline $\mathrm{pH}$ values for both laccase preparations, $\mathrm{L}_{T v}$ and $\mathrm{L}_{S c}$, is advantageous for the targeted applications in municipal wastewater ( $\mathrm{pH} 7-8$ ). Although laccases are known to be relatively stable at ambient temperatures and near-neutral $\mathrm{pH}$, this is, however, the first time that long-term stability (45-60\% remaining activity after incubation $55 \mathrm{~d}$ at $25^{\circ} \mathrm{C}$ ) was reported for these two particular laccase preparations.

\section{Laccase substrate range and oxidation of micropollutants}

The broader the laccase substrate range is, the greater the potential for the enzyme to be used to remove micropollutants. Both laccases were able to oxidize the four aromatic model substrates tested, showing higher activity against the non-phenolic ABTS, followed by the phenolic compounds DMP, syringladazine and finally guaiacol. $\mathrm{L}_{S c}$ was much less active on the phenolic substrates than on ABTS compared to $\mathrm{L}_{T v}$. These differences in reactivity are reported to be related to differences in shape and chemical composition of the substrate binding site of the enzymes (Rosado et al. 2012; Xu et al. 1996). Differences in the phenol substitution seemed also to influence the activity. The electron-donating property of the methoxy group is reported to reduce the redox potential of phenolic compounds, guaiacol (1 methoxy group) having a higher redox potential $E^{0}$ than the two other substrates (2 methoxy groups) (Xu 1996). For small $o$-substituted phenols, the redox potential difference $\left(\Delta E^{0}\right)$ between laccase type 1 copper site (T1) and the substrate seems to be the main driving force for the oxidation (Xu 1996). Therefore, the lower the $E^{0}$ value of the phenolic substrate, the faster will be the reaction rate, which is consistent with the results obtained here. For larger $o$-substituents, other significant mechanisms such as steric hindrance may be observed (Xu 1996).

BPA, DFC and MFA are three common micropollutants found at relatively high concentrations in municipal WWTP effluent (average between 300-1000 ng l-1) (Kase et al. 2011). DFC is of special concern because it is not removed in conventional biological treatments (Margot et al. 2013a) and can affect fish at typical WWTP effluent concentrations $\left(1 \mathrm{gg} \mathrm{l}^{-1}\right)$ (Triebskorn et al. 2004). Despite their very low activity at $\mathrm{pH} 7$ on the model substrates, both laccases were able to reduce the concentration of these micropollutants significantly at neutral $\mathrm{pH}$, which is for the first time reported for bacterial laccases. The oxidation rates were much higher at $\mathrm{pH} 7$ with $\mathrm{L}_{T V}$ compared to $\mathrm{L}_{S c}$, especially for the two aniline pollutants (DFC and MFA), confirming the wider $\mathrm{pH}$ range of this enzyme. $\mathrm{L}_{S c}$ was less reactive with aniline (DFC and MFA) than with phenol compounds (BPA) compared to $\mathrm{L}_{T v}$. Both laccases rapidly oxidized $\mathrm{BPA}$, with a similar rate at $\mathrm{pH} 5$, while $\mathrm{L}_{T v}$ was more effective for the oxidation of the two aniline compounds at all $\mathrm{pH}$ values. This difference in oxidation rate is thought to be either related to different affinity for the aniline substrates or to a lower redox potential of the T1 copper site of $\mathrm{L}_{S c}$, as observed for many other bacterial laccases $\left(E^{0}<0.5 \mathrm{~V}\right.$ vs. SHE, compared to $0.785 \mathrm{~V}$ for $\left.\mathrm{L}_{T v}\right)$ (Hong et al. 2011; Telke et al. 2009).

The higher DFC degradation with $\mathrm{L}_{T v}$ at $\mathrm{pH} 6$ than at pH 5 contrasts with a previous study where the highest removal was observed below pH 5 (Margot et al. 2013b). This shift in the optimal pH is likely due to the different initial enzyme concentrations used, 3.5 times higher in the previous study. At low enzyme concentrations, the oxidation rate was slower and the time to reach a defined level of micropollutant removal longer. The longer the reaction time, the higher was the loss of laccase by inactivation, especially under acidic conditions. Thus, in case of low enzyme concentration, the gain associated with higher laccase activity at lower $\mathrm{pH}$ was offset by the loss of activity at these $\mathrm{pH}$ values due to the long reaction time. Higher degradation levels were thus observed at higher $\mathrm{pH}$, where laccase was more stable. The loss of activity was limited in case of high enzyme concentrations (fast reaction) and thus higher degradation levels were obtained at a lower $\mathrm{pH}$ value (close to the optimal $\mathrm{pH}$ for laccase activity). Therefore, depending on the laccase concentration, a compromise between laccase stability (higher at high $\mathrm{pH}$ values) and laccase activity (higher at low $\mathrm{pH}$ values) has to be found to determine the optimal $\mathrm{pH}$ for the treatment.

The evaluation of five laccase-producing organisms to improve micropollutant degradation in wastewater showed that $T$. versicolor was the most promising strain. This fungus produced more than 20-times more laccase activity than S. cyaneus, the best candidate of the Streptomyces strains evaluated, and this especially in treated wastewater with forestry waste as the sole substrate, a cheap and widely available product. Laccase from $T$. versicolor $\left(\mathrm{L}_{T v}\right)$ was moreover more active than that from S. cyaneus $\left(\mathrm{L}_{S c}\right)$ near neutral $\mathrm{pH}$ and between 10 to $25^{\circ} \mathrm{C}$, conditions usually found in municipal wastewater. Despite an optimal activity under acidic conditions $(\mathrm{pH}<6)$, which limits their use in non-acidified wastewater, both laccases had the ability to degrade common wastewater micropollutants, BPA, DFC and MFA even at neutral $\mathrm{pH}$, which is for the first time reported for a bacterial laccase. Micropollutant oxidation was faster with $\mathrm{L}_{T v}$, especially for aniline pollutants, showing the greater potential of this enzyme for the target application. Both laccases were relatively stable at slightly alkaline $\mathrm{pH}$ values, conditions found in municipal wastewater. Thus, altogether, despite a slightly lower resistance of its laccase to chloride, $T$. versicolor appeared to be the best candidate to be used in a post-treatment, such as a fungal trickling filter composed of wood support, for micropollutant degradation in wastewater. 


\section{Additional file}

\section{Additional file 1: Supplementary data associated with this article} can be found in the online version.

\section{Competing interests}

The authors declare that they have no competing interests.

\section{Acknowledgments}

We acknowledge Teresa Vicent (Universitat Autonoma de Barcelona) and Nevenka Adler (EPFL) for their proof reading and advice on the manuscript

\section{Author details}

${ }^{1}$ Laboratory for Environmental Biotechnology, School of Architecture, Civil and Environmental Engineering (ENAC), Station 6, Ecole Polytechnique Fédérale de Lausanne (EPFL), 1015 Lausanne, Switzerland. ²Ecological Engineering Laboratory, School of Architecture, Civil and Environmental Engineering (ENAC), Station 2, Ecole Polytechnique Fédérale de Lausanne (EPFL), 1015 Lausanne, Switzerland. ${ }^{3}$ Departament d'Enginyeria Química, Escola d'Enginyeria, Universitat Autònoma de Barcelona (UAB), 08193 Bellaterra, Spain. ${ }^{4}$ Present address: Unité de Biotechnologie des Champignons Filamenteux, Institut National de le Recherche Agronomique (INRA)/Universités de Provence et de la Méditerranée, Ecole Supérieure des Ingénieurs de Luminy, 163 avenue de Luminy-CP 925, 13288 Cedex 09, Marseille, France.

Received: 11 October 2013 Accepted: 14 October 2013

Published: 24 October 2013

\section{References}

Alan MV, Barber LB, Gray JL, Lopez EM, Woodling JD, Norris DO (2008) Reproductive disruption in fish downstream from an estrogenic wastewater effluent. Environ Sci Technol 42(9):3407-3414

Arias ME, Arenas M, Rodríguez J, Soliveri J, Ball AS, Hernández M (2003) Kraft pulp biobleaching and mediated oxidation of a nonphenolic substrate by laccase from Streptomyces cyaneus CECT 3335. Appl Environ Microbiol 69(4):1953-1958

Auriol M, Filali-Meknassi Y, Adams CD, Tyagi RD, Noguerol TN, Pina B (2008) Removal of estrogenic activity of natural and synthetic hormones from a municipal wastewater: efficiency of horseradish peroxidase and laccase from Trametes versicolor. Chemosphere 70(3):445-452

Aymard C, Belarbi A (2000) Kinetics of thermal deactivation of enzymes: a simple three parameters phenomenological model can describe the decay of enzyme activity, irrespectively of the mechanism. Enzyme Microb Technol 27(8):612-618

Blánquez P, Casas N, Font X, Gabarrell X, Sarrà M, Caminal G, Vicent T (2004) Mechanism of textile metal dye biotransformation by Trametes versicolor. Water Res 38(8):2166-2172

Blánquez P, Sarrà M, Vicent MT (2006) Study of the cellular retention time and the partial biomass renovation in a fungal decolourisation continuous process. Water Res 40(8):1650-1656

Blánquez P, Sarrà M, Vicent T (2008) Development of a continuous process to adapt the textile wastewater treatment by fungi to industrial conditions. Process Biochem 43(1):1-7

Bourbonnais R, Paice MG, Reid ID, Lanthier P, Yaguchi M (1995) Lignin oxidation by laccase isozymes from Trametes versicolor and role of the mediator 2,2'-azinobis(3-ethylbenzthiazoline-6-sulfonate) in kraft lignin depolymerization. Appl Environ Microbiol 61(5):1876-1880

Bugg TDH, Ahmad M, Hardiman EM, Singh R (2011) The emerging role for bacteria in lignin degradation and bio-product formation. Curr Opin Biotechnol 22(3):394-400

Bundschuh M, Pierstorf R, Schreiber WH, Schulz R (2011) Positive effects of wastewater ozonation displayed by in situ bioassays in the receiving stream Environ Sci Technol 45(8):3774-3780

Cabana H, Jiwan JLH, Rozenberg R, Elisashvili V, Penninckx M, Agathos SN, Jones JP (2007) Elimination of endocrine disrupting chemicals nonylphenol and bisphenol a and personal care product ingredient triclosan using enzyme preparation from the white rot fungus Coriolopsis polyzona. Chemosphere 67(4):770-778
Childs RE, Bardsley WG (1975) The steady state kinetics of peroxidase with 2,2' azino di (3 ethylbenzthiazoline 6 sulphonic acid) as chromogen. Biochem J 145(1):93-103

Crain DA, Eriksen M, Iguchi T, Jobling S, Laufer H, LeBlanc GA, Guillette LJ Jr (2007) An ecological assessment of bisphenol-A: evidence from comparative biology. Reprod Toxicol 24(2):225-239

De Souza CGM, Tychanowicz GK, De Souza DF, Peralta RM (2004) Production of laccase isoforms by Pleurotus pulmonarius in response to presence of phenolic and aromatic compounds. J Basic Microbiol 44(2):129-136

Deblonde T, Cossu-Leguille C, Hartemann P (2011) Emerging pollutants in wastewater: a review of the literature. Int J Hyg Envir Heal 214(6):442-448

Dwivedi UN, Singh P, Pandey VP, Kumar A (2011) Structure-function relationship among bacterial, fungal and plant laccases. J Mol Catal B Enzym 68(2):117-128

Eichlerová I, Šnajdr J, Baldrian P (2012) Laccase activity in soils: considerations for the measurement of enzyme activity. Chemosphere 88(10):1154-1160

Enaud E, Trovaslet M, Naveau F, Decristoforo A, Bizet S, Vanhulle S, Jolivalt C (2011) Laccase chloride inhibition reduction by an anthraquinonic substrate. Enzyme Microb Technol 49(6-7):517-525

Endo K, Hosono K, Beppu T, Ueda K (2002) A novel extracytoplasmic phenol oxidase of Streptomyces: its possible involvement in the onset of morphogenesis. Microbiology 148(6):1767-1776

Fernández-Fernández M, Sanromán MÁ, Moldes D (2012) Recent developments and applications of immobilized laccase. Biotechnol Adv, http://dx.doi.org/ 10.1016/j.biotechadv.2012.02.013

Gagné F, Bouchard B, André C, Farcy E, Fournier M (2011) Evidence of feminization in wild Elliptio complanata mussels in the receiving waters downstream of a municipal effluent outfall, comp biochem physiol C. Pharmacol Toxicol 153(1):99-106

Garcia HA, Hoffman CM, Kinney KA, Lawler DF (2011) Laccase-catalyzed oxidation of oxybenzone in municipal wastewater primary effluent. Water Res 45 (5):1921-1932

Gianfreda L, Xu F, Bollag J-M (1999) Laccases: a useful group of oxidoreductive enzymes. Biorem J 3(1):1-26

Harkin JM, Rowe JW (1971) Bark and its possible uses. U.S. Forest service research legacy. Forest Products Laboratory (U.S.), Madison, Wisconsin, USA, www.fpl.fs.fed.us/documnts/fplrn/fplrn091.pdf

Harms H, Schlosser D, Wick LY (2011) Untapped potential: exploiting fungi in bioremediation of hazardous chemicals. Nat Rev Microbiol 9(3):177-192

Hong G, Ivnitski DM, Johnson GR, Atanassov P, Pachter R (2011) Design parameters for tuning the type 1 Cu multicopper oxidase redox potential: Insight from a combination of first principles and empirical molecular dynamics simulations. J Am Chem Soc 133(13):4802-4809

Kase R, Eggen RIL, Junghans M, Götz C, Hollender J (2011) Assessment of micropollutants from municipal wastewater - Combination of exposure and ecotoxicological effect data for Switzerland. In: Einschlag F (ed) Waste water evaluation and management. InTech, Rijeka, Croatia, pp 31-54

Koduri RS, Tien M (1995) Oxidation of guaiacol by lignin peroxidase: role of veratryl alcohol. J Biol Chem 270(38):22254-22258

Koschorreck K, Richter SM, Swierczek A, Beifuss U, Schmid RD, Urlacher VB (2008) Comparative characterization of four laccases from Trametes versicolor concerning phenolic C-C coupling and oxidation of PAHs. Arch Biochem Biophys 474(1):213-219

Kurniawati S, Nicell JA (2008) Characterization of Trametes versicolor laccase for the transformation of aqueous phenol. Bioresour Technol 99(16):7825-7834

Lefebvre O, Moletta R (2006) Treatment of organic pollution in industrial saline wastewater: a literature review. Water Res 40(20):3671-3682

Leutz RC (1974) The recovery of sodium chloride from sea water. Int J Miner Process 1(2):163-171

Libra JA, Borchert M, Banit S (2003) Competition strategies for the decolorization of a textile-reactive dye with the white-rot fungi Trametes versicolor under non-sterile conditions. Biotechnol Bioeng 82(6):736-744

Lu J, Huang Q, Mao L (2009) Removal of acetaminophen using enzyme-mediated oxidative coupling processes: I. Reaction rates and pathways. Environ Sci Technol 43(18):7062-7067

Mai C, Schormann W, Milstein O, Hüttermann A (2000) Enhanced stability of laccase in the presence of phenolic compounds. Appl Microbiol Biotechnol 54(4):510-514

Marco-Urrea E, Pérez-Trujillo M, Blánquez P, Vicent T, Caminal G (2010) Biodegradation of the analgesic naproxen by Trametes versicolor and identification of intermediates using HPLC-DAD-MS and NMR. Bioresour Technol 101(7):2159-2166 
Margot J, Kienle C, Magnet A, Weil M, Rossi L, de Alencastro LF, Abegglen C, Thonney D, Chèvre N, Schärer M, Barry DA (2013a) Treatment of micropollutants in municipal wastewater: ozone or powdered activated carbon? Sci Total Environ 461-462:480-498

Margot J, Maillard J, Rossi L, Barry DA, Holliger C (2013b) Influence of treatment conditions on the oxidation of micropollutants by Trametes versicolor laccase. N Biotechnol 30(6):803-813

Moldes D, Sanromán MA (2006) Amelioration of the ability to decolorize dyes by laccase: relationship between redox mediators and laccase isoenzymes in Trametes versicolor. World J Microbiol Biotechnol 22(11):1197-1204

Moldes D, Lorenzo M, Sanromán MA (2004) Different proportions of laccase isoenzymes produced by submerged cultures of Trametes versicolor grown on lignocellulosic wastes. Biotechnol Lett 26(4):327-330

Molina-Guijarro JM, Pérez J, Muñoz-Dorado J, Guillén F, Moya R, Hernández M, Arias ME (2009) Detoxification of azo dyes by a novel pH-versatile, saltresistant laccase from Streptomyces ipomoea. Int Microbiol 12(1):13-21

Moya R, Hernández M, García-Martín AB, Ball AS, Arias ME (2010) Contributions to a better comprehension of redox-mediated decolouration and detoxification of azo dyes by a laccase produced by Streptomyces cyaneus CECT 3335 . Bioresour Technol 101(7):2224-2229

Muñoz C, Guillén F, Martínez AT, Martínez MJ (1997) Laccase isoenzymes of Pleurotus eryngii: characterization, catalytic properties, and participation in activation of molecular oxygen and $\mathrm{Mn}^{2+}$ oxidation. Appl Environ Microbiol 63(6):2166-2174

Nakatani M, Hibi M, Minoda M, Ogawa J, Yokozeki K, Shimizu S (2010) Two laccase isoenzymes and a peroxidase of a commercial laccase-producing basidiomycete, Trametes sp. Ha1. N Biotechnol 27(4):317-323

Niladevi KN, Prema P (2008) Effect of inducers and process parameters on laccase production by Streptomyces psammoticus and its application in dye decolourization. Bioresour Technol 99(11):4583-4589

Niladevi KN, Jacob N, Prema P (2008) Evidence for a halotolerant-alkaline laccase in Streptomyces psammoticus: purification and characterization. Process Biochem 43(6):654-660

Niladevi KN, Sukumaran RK, Jacob N, Anisha GS, Prema P (2009) Optimization of laccase production from a novel strain Streptomyces psammoticus using response surface methodology. Microbiol Res 164(1):105-113

Nyanhongo GS, Guebitz G, Sukyai P, Leitner C, Haltrich D, Ludwig R (2007) Oxidoreductases from Trametes spp. in biotechnology: a wealth of catalytic activity. Food Technol Biotech 45(3):250-268

Özşölen F, Aytar P, Gedikli S, Çelikdemir M, Ardiç M, Çabuk A (2010) Enhanced production and stability of laccase using some fungi on different lignocellulosic materials. J Appl Biol Sci 4(3):69-78

Palmieri G, Giardina P, Bianco C, Scaloni A, Capasso A, Sannia G (1997) A novel white laccase from Pleurotus ostreatus. J Biol Chem 272(50):31301-31307

Parenti A, Muguerza E, Redin Iroz A, Omarini A, Conde E, Alfaro M, Castanera R, Santoyo F, Ramírez L, Pisabarro AG (2013) Induction of laccase activity in the white rot fungus Pleurotus ostreatus using water polluted with wheat straw extracts. Bioresour Technol 133:142-149

Rajkumar D, Palanivelu K (2004) Electrochemical treatment of industrial wastewater. J Hazard Mater 113(1-3):123-129

Rancaño G, Lorenzo M, Molares N, Couto SR, Sanromán MÁ (2003) Production of laccase by Trametes versicolor in an airlift fermentor. Process Biochem 39(4):467-473

Reiss R, Ihssen J, Thöny-Meyer L (2011) Bacillus pumilus laccase: a heat stable enzyme with a wide substrate spectrum. BMC Biotechnol 11:9

Rosado T, Bernardo P, Koci K, Coelho AV, Robalo MP, Martins LO (2012) Methyl syringate: an efficient phenolic mediator for bacterial and fungal laccases. Bioresour Technol 124:371-378

Sadana A (1988) Enzyme deactivation. Biotechnol Adv 6(3):349-446, IN1-IN2

Schwarz J, Aust M-O, Thiele-Bruhn S (2010) Metabolites from fungal laccase-catalysed transformation of sulfonamides. Chemosphere 81(11):1469-1476

Sharma P, Goel R, Capalash N (2007) Bacterial laccases. World J Microbiol Biotechnol 23(6):823-832

Shirling EB, Gottlieb D (1966) Methods for characterization of Streptomyces species. Int J Syst Bacteriol 16(3):313-340

Silvério SC, Rodríguez O, Tavares APM, Teixeira JA, Macedo EA (2013) Laccase recovery with aqueous two-phase systems: enzyme partitioning and stability. J Mol Catal B Enzym 87:37-43

Strong PJ, Claus H (2011) Laccase: a review of its past and its future in bioremediation. Crit Rev Env Sci Technol 41(4):373-434
Suda T, Hata T, Kawai S, Okamura H, Nishida T (2012) Treatment of tetracycline antibiotics by laccase in the presence of 1-hydroxybenzotriazole. Bioresour Technol 103(1):498-501

Telke AA, Kalyani DC, Jadhav UU, Parshetti GK, Govindwar SP (2009) Purification and characterization of an extracellular laccase from a Pseudomonas sp LBC1 and its application for the removal of bisphenol A. J Mol Catal B Enzym 61(3-4):252-260

Torres-Duarte C, Roman R, Tinoco R, Vazquez-Duhalt R (2009) Halogenated pesticide transformation by a laccase-mediator system. Chemosphere 77(5):687-692

Triebskorn R, Casper H, Heyd A, Eikemper R, Köhler HR, Schwaiger J (2004) Toxic effects of the non-steroidal anti-inflammatory drug diclofenac: Part II. Cytological effects in liver, kidney, gills and intestine of rainbow trout (Oncorhynchus mykiss). Aquat Toxicol 68(2):151-166

Xu F (1996) Oxidation of phenols, anilines, and benzenethiols by fungal laccases: correlation between activity and redox potentials as well as halide inhibition. Biochemistry 35(23):7608-7614

Xu F (1997) Effects of redox potential and hydroxide inhibition on the pH activity profile of fungal laccases. J Biol Chem 272(2):924-928

Xu F, Shin W, Brown SH, Wahleithner JA, Sundaram UM, Solomon El (1996) A study of a series of recombinant fungal laccases and bilirubin oxidase that exhibit significant differences in redox potential, substrate specificity, and stability. Biochim Biophys Acta Protein Struct Mol Enzymol 1292(2):303-311

Yang Y, Ding Y, Liao X, Cai Y (2013) Purification and characterization of a new laccase from Shiraia sp. SUPER-H168. Process Biochem 48(2):351-357

Zhang Y, Geißen SU (2012) Elimination of carbamazepine in a non-sterile fungal bioreactor. Bioresour Technol 112:221-227

doi:10.1186/2191-0855-3-63

Cite this article as: Margot et al: Bacterial versus fungal laccase: potential for micropollutant degradation. AMB Express 2013 3:63.

\section{Submit your manuscript to a SpringerOpen ${ }^{\circ}$ journal and benefit from:}

- Convenient online submission

- Rigorous peer review

- Immediate publication on acceptance

- Open access: articles freely available online

High visibility within the field

- Retaining the copyright to your article

Submit your next manuscript at $\gg$ springeropen.com 